\title{
Multilingual Education in Europe: Policy Developments
}

\author{
José Manuel Vez \\ Atrium Linguarum Observatory, Institute of Education Sciences, University of Santiago de \\ Compostela
}

Received: 29 May 2008 / Accepted: 12 December 2008

ISSN: 1697-7467

\begin{abstract}
In order to gain ground in the Europe of knowledge, we must make sure that pupils in all EU countries receive the appropriate education and develop the right knowledge and skills, including intercultural and plurilingual competences. But how successful a cohesive process for a multilingual Europe is it likely to be? In which way do new policy developments in language education affect curriculum decision-making, professionalism and our own sense of identity and intercultural options? Up to which point do 'linguistic unity' and 'linguistic diversity' have to be taken into account as political and educational factors gearing towards European communicative integration? How can we avoid policy developments which treat multilingualism as an 'either - or' decision and run the risk of creating social exclusion either through cultural or linguistic exclusion? Is it possible in a multilingual Europe to develop a holistic language education policy inclusive of 'Global English' and linguistic diversity? This article addresses these questions by examining the effectiveness as policy development mechanisms of the introduction of changes to policy and/or school practices that require modification or renovation of language education. This examination incorporates analysis of the concept and substance of multilingualism as part of European integration and offers new perspectives on how it may be interpreted and utilised for the development of education policies in EU countries.
\end{abstract}

Key Words: Multilingualism, plurilingual competences, language education, CLIL, language policies.

\section{Educación plurilingüe en Europa: medidas políticas}

RESUMEN: Con el objetivo de avanzar en la construcción de una Europa del conocimiento es preciso asegurarse de que los niños en todos los países europeos reciben una adecuada educación, con un buen desarrollo competencial, que incluya competencias plurilingües e interculturales. Pero: ¿qué probabilidades tenemos de lograr un proceso cohesivo a favor de una Europa multilingüe?; ¿de qué modo están afectando las nuevas medidas políticas de desarrollo de la educación lingüística a las decisiones curriculares, a la profesionalización docente y a nuestro propio sentido de la identidad y de las opciones interculturales?; ¿hasta qué punto la 'unidad lingüística' y la 'diversidad lingüística' deben tenerse en cuenta como factores políticos y educativos que nos lleven hacia una integración comunicativa europea?; ¿cómo podemos evitar acciones de política educativa que traten el multilingüismo como una decisión opcional, corriendo el riesgo de 
crear exclusión social por medio de la marginación cultural o lingüística?; ¿es posible en una Europa multilingüe poner en juego políticas integrales de educación lingüística que incluyan al 'Global English' al tiempo que a la diversidad de lenguas? Este artículo trata de dar respuesta a estos interrogantes mediante el análisis de la introducción de cambios, como formas de políticas educativas, en las prácticas de los centros escolares con vista a la modificación o renovación de la didáctica de las lenguas. Esta revisión incorpora el análisis del concepto y la sustancia de multilingüismo como parte de la integración europea, y ofrece nuevas perspectivas acerca de cómo se puede interpretar y aplicar en el desarrollo de políticas educativas en los países de la Unión Europea.

Palabras clave: Multilingüismo, competencias plurilingües, educación lingüística, AICLE, políticas lingüísticas.

\section{INTRODUCTION}

The European dimension in language education, it is generally believed, is not what it was. Globalisation, European Union (EU) policies, migrant movements and Global English are changing the languages and cultures of European nations in some way. And it is arguable that some continental European languages are on a fast track to second-class status. Depending on one's perspective, we are moving too slow or too fast on our way towards European integration through multilingual education ${ }^{1}$. It is clear that with mainstream language teaching (language as subjects-matters in themselves), characterized as drip-feed education, we were on the slow way.

The study of foreign languages at school was a privilege of the youth of higher social classes until the second part of the 20th century and only recently have many old 'minority languages' in Europe (e.g. Galician in Spain, Lapp in Nordic countries) got the status of 'minority State language' and are taught at school as home language or as mother tongue (Alcón and Safont, 2008; Bathia and Ritchie, 2004; Christian and Genesee, 2001).

While concrete language policies of the member states of the EU differ to a certain extent -from (pro-)activity towards extensive diversity to rather monolingual policies-, the European Commission and the Council of Europe follow a quite similar aim: diversity and multilingualism. As Leonard Orban, EU Commissioner for Multilingualism, has recently put it:

1 The terms multilingual education, bilingual education, and mother tongue education have been used in various ways in the literature. In this paper, these terms are used as follows: i) Mother tongue education implies a linguistically homogeneous community, a teacher who speaks this language, and curriculum materials in the mother tongue. It is worth noting that mother tongue education is the norm in most western nations; ii) Bilingual education is used to refer to an educational scheme in which the child receives educational instruction in at least two languages with one of these being the mother tongue of some/all of the children in the classroom.

The second language is normally a language of wider communication, often the official or national language; and iii) Multilingual education is used primarily as a synonym for bilingual education. The primary difference, when it is a difference, is that multilingual education schemes may well involve three or more languages rather than just two. Even so, it is still assumed that the mother tongue will normally be a part of the early educational experience of the child. 
From the moment I took up this portfolio, the interface between business and languages has been one of my priorities. Multilingualism is a plusfactor for European integration, competitiveness, and growth and better jobs. Our challenge is to get the message across to business and to education, and to arm companies and individuals with the language tools and strategies for success. Multilingualism touches citizens directly. Just an example: over 2400 responses to our on-line languages consultation this autumn, when, often, the Commission is receiving a couple of hundred. This is not surprising. Citizens view this policy as a means to articulate a democratic right: to understand EU policy and to be understood by the institutions. Seen from this perspective, the cost of multilingualism -roughly the price of a coffee per citizen per year- is negligible and, in any event, is the cost of democracy. (SPEECH/07; p. 2 [6 December 2007]. Retrieved in March 26, 2008, from http://ec.europa.eu/commission_barroso/ orban/index_en.htm)

Under the motto 'Many people speaking many languages', Leonard Orban sees multilingualism both as the ability to speak the language of others and of others to speak our language. Promoting multilingualism in the different policies of the EU, such as culture, education, communication and employment is at the centre of his objectives and he firmly believes that languages do open up new opportunities, doors to new experiences; and they can signpost the way towards a more inclusive, prosperous Europe for all citizens. But, do they?

\section{The European Schools: A MOdel For Developing Multilingual EDUCATION?}

The European Schools (ES) have been in operation for nearly 50 years in several member states of the EU and have gained a firm reputation as examples of both linguistic and scholastic excellence (Baker, 1996; Hamers and Blanc, 1989). Recent years have also seen a growing interest in ES as a model for developing multilingual education elsewhere (European Economic Community, 1990; Skutnabb-Kangas, 1995). In this light, it is important to draw attention to the available research on processes and outcomes in these schools and to the lessons that can be drawn from their experience.

The ES provide high-quality multicultural and multilingual education to the children of the staff of the EU institutions, but most ES pupils are language minority children in the sense that their home language is not the majority language of the host community where the school is located. Although it is not part of any policy, most students come from middle class families, which contributes to the ES' reputation as elitist schools (Baker, 1996; Hamers and Blanc, 1989; Sears, 1998). When possible, efforts are made to enrol children from non-EU officials (including host nationals and immigrant children) to avoid 'ghetto-ization' and to balance out the numbers in the various language sections. An important mission of the ES is to develop a pluralistic identity and to prepare pupils for life in linguistically and culturally heterogeneous societies. This implies additive multilingualism, with high levels of functional proficiency and literacy in at least two languages: the child's home language and one of the school working languages.

But, how should we conceive the notion of multilingual education envisaged by the ES model? I think it entails two seemingly contradictory goals, namely the maintenance of the 
child's distinct home culture and national identity on the one hand and the development of a supra-national European identity. Minimally, ethno-linguistic prejudices and overly nationalistic sentiments are to be prevented, I should say. Indeed, Baetens (1995) refers to the process of 'social engineering' provided as a deliberate mixing of pupils from different national and linguistic backgrounds for as many subjects and activities as possible. So the aim of 'social engineering' is both to minimalise fragmentation of the school population on nationalisticlinguistic lines (a risk inherent to the presence of different language sections on the same site) and to enhance the foreign language education process.

Although some observers (Baetens and Swain, 1985; Baetens, 1993; Housen, 2002; Housen and Pallotti, 2002) point to the high success rates of ES students in the final examinations leading to the European baccalaureate (in excess of 90\%) and to the large proportion of ES pupils who progress to higher education, often in countries where the L2 rather than the L1 is spoken, it is necessary to note -from a more critical observation- that ES pupils are held back in secondary school if their overall attainment does not meet the educational goals set for the grade. Similarly, they have to leave the school after having been held back twice. Empirical evidence (Hoffman, 1998; Housen, 1997) supports the argument that this practice, plus the fact that less academically inclined pupils may leave the program of their own accord, has to be taken into account when interpreting the reported high levels of academic success in the ES.

The carefully engineered ES program teaches languages and other subjects in the target language and regularly juxtaposes different language groups, creating daily possibilities for communication in the language inside and outside the classroom. From the insights gained so far, supported by insights from other bilingual and multilingual programs (Cenoz and Jessner, 2000; De Bot, Lowie and Verspoor, 2007; Muller and Beardsmore, 2004), several general observations can be made for ensuring successful multilingual education in general:

- Multilingual education for majority language students is effective in promoting functional proficiency in a second, and even third or fourth, language at no cost to the participating students' mother language development or academic achievement.

There is often a positive correlation between amount of exposure to the additional languages in multilingual programs and level of plurilingual proficiency, but not always.

- Multilingual programs that provide appropriate and continuous instruction can be effective with younger or older students; in other words, advanced levels of functional plurilingual proficiency can be acquired by students who begin multilingual education in the primary grades and by those who begin in higher grades.

- Multilingual education is effective for majority language students with a variety of learner characteristics, even those that put them at-risk for poor performance in EU schools.

- Pedagogy and, in particular, the way the additional languages are used and taught is important. More specifically, it appears that plurilingual acquisition is enhanced when students are given extended opportunities to use the language interactively. It also appears that while functional use of the target languages is generally effective at promoting plurilingual competences, instructional strategies that systematically raise awareness of and create opportunities for students to learn specific linguistic 
forms that serve their communicative needs and goals can extend the learning of new languages.

- Multilingual education in languages with distinct typologies and orthographic conventions can be effective in achieving a school's linguistic and academic objectives, although there may be limits on how far these languages can be used for academic instruction.

But success in multilingual education is ultimately determined by a myriad of factors, curricular as well as extra-curricular, some of which may well be beyond the control of program designers. For example, what are the limits to acquisition of three or more languages when there is no or little support for the non-native languages outside school? More research is needed to establish the exact weight of these factors, and their interactions, in determining outcomes in the ES as a model of multilingual education. From this reasoning, and given the EU complexity and the dearth of research-based knowledge about its functioning and outcomes, my current thinking leads me to consider that it would clearly be inappropriate to transplant the ES model to other contexts.

\section{Policies within the context of the Council of Europe and the European Commission}

The Council of Europe (CE), including now (end of 2008) 47 member States, is very active in enhancing Europe's cultural heritage promoting unity in diversity particularly in educational fields. The $\mathrm{CE}$ has for long run cross-European projects focusing on the transmission of democratic values to young people and preparing them for life in a multilingual and multicultural Europe (Council of Europe, 2000). For one of its outstanding cross-European projects, the Modern Language Project, the Council has defined objectives, such as:

- to promote large-scale multilingualism by assisting member states in encouraging all Europeans to achieve a degree of communicative ability in a number of languages and to continue their language learning on a lifelong basis;

- diversifying the range of languages on offer and setting appropriate objectives for each language;

- improving the education/training of language teachers and promoting learner-centred, communicative methodologies.

Another large project of the CE, Language Policies for a Multilingual and Multicultural Europe (1997-2000), has the following aims:

- to help national authorities to promote multilingualism and multiculturalism and to increase public awareness of the part played by languages in forging a European identity;

- to develop ideas, approaches and strategies to promote linguistic diversification and to improve the quality of language education;

- to promote foreign language learning from the very start of schooling, making every pupil aware of Europe's linguistic and cultural diversity; 
- to develop further and apply common European reference instruments for planning and assessments of language learning, mutual recognition of qualifications and coordination of politics;

- to elaborate instruments and co-ordinate networks for the design and implementation of modular courses;

- to develop further the intercultural dimension in language education.

The European Commission (EC), for its part, is following a very (pro-)active language policy focusing on diversity. One of the most influential items may be seen in the recommendations contained in the White Book-Teaching and Learning: Towards the Learning Society. Concerning language education, they may be summarised as follows:

- Every EU citizen should be able to use three community languages (after completion of secondary school).

- Community language learning should be developed 'as early as possible'.

- A better quality of language and intercultural learning must be improved, and a more balanced language ecology should be promoted;

- Increasing language competence increases mobility and also gives better possibilities for seeking jobs in different EU member states.

The CE and the EC declared 2001 as the European Year of Languages. The reason is that Europeans should become more aware of the need to develop reasonable competence in several languages (Sheils, 1999). The argument is clearly for diversity. The increase in the scale and quality of language learning has been concentrated on the English language, and this fact is perceived as problematic by education policy makers. Restricting foreign language learning to ensure a common knowledge of English as a universal second language might erect barriers to young Europeans' appreciation of the rich cultural diversity of the continent and full participation in the cultural life of different countries (Trim, 1999). Therefore, it is important to promote the learning of less widely used or taught languages (Sheils, 1999). As Leonard Orban, Commissioner of Multilingualism, suggests:

Languages and multilingualism are part and parcel of this enlarged Europe. We all belong to a Union which sets a high value on its diversity, which is European because of and not in spite of this diversity. In this diverse Europe, languages are bridges that give us the means to communicate with each other, to understand each other's cultures, to build on our shared values. (Speech/08/132: 1 [7 March 2008]. Retrieved April 10, 2008. Available at:

http://ec.europa.eu/commission_barroso/orban/index_en.htm)

How do these policies affect multilingual education in schools? The two enlargements of 2004 and 2007, with the expansion from 11 to 23 languages, have indeed marked a turning point for European multilingualism in our education system. The EU communication ' $\mathrm{COM}$ 2005595 final', A New Framework Strategy for Multilingualism, sets very clearly the positions of two related parameters -multilingualism and European values:

The European Union is founded on 'unity in diversity': diversity of cultures, customs and beliefs -and of languages. Besides the $20^{2}$ official languages of the Union, there are 60 or so

2. 21 with the inclusion of Irish from 2007; 23 when Bulgarian and Romanian were added. 
other indigenous languages and scores of non-indigenous languages spoken by migrant communities. $^{3}$

It is this diversity that makes the European Union what it is: not a 'melting pot' in which differences are rendered down, but a common home in which diversity is celebrated, and where our many mother tongues are a source of wealth and a bridge to greater solidarity and mutual understanding.

Language is the most direct expression of culture; it is what makes us human and what gives each of us a sense of identity. Article 22 of the Charter of Fundamental Rights of the European Union ${ }^{4}$ states that the Union shall respect cultural, religious and linguistic diversity. (European Commission, 2005: 2)

According to key data provided by the Eurydice report on the teaching of languages at school in Europe (Eurydice, 2005), the percentage of primary school pupils learning a foreign language is increasing but the average number of foreign languages taught in secondary schools is still some way from the target set in Barcelona ${ }^{5}$. In that sense, the Commission's conclusion (EU, 2005: 4) is unambiguous when it asserts that 'There is a growing tendency for 'foreign language learning' to mean simply 'learning English'; the Commission has already pointed out that 'English is not enough' (COM [2003] 449).

And how far can policy deciders design language education policies which really promote a global and coherent approach to plurilingual education? We find the answer to this question in the Council's publication known as 'The Guide' -From Linguistic Diversity to Plurilingual Education: Guide for the Development of Language Education Policies in Europe (Council of Europe, 2007). The current Main Version of the Guide is a document which has been enriched and reorganised by means of a consultation process which took place between the Conference 'Languages, Diversity, Citizenship: Policies for plurilingualism in Europe' (Strasbourg, 13-15 November 2002) and the policy Forum 'Global Approaches to Plurilingual Education' (Strasbourg, 28-29 June 2004).

Defending the position that EU policies for language education should promote the acquisition of several languages to different levels at different times, the Guide deals with policy developments both in schools and formal education and in lifelong learning. By describing how language education policy can provide an inclusive and coherent view of multilingual education, its concern is with the 'whole' of language education, including education in the mother tongue when it is the official and/or national language of the area in question. So it is significant to indicate that the Guide is not concerned only with 'foreign', 'second', or 'minority' languages.

One final point I want to examine here has to do with the educational tools provided within this context and which, in practical terms, can help both schools and language professionals. Schools and language professionals naturally have an essential role to play in allowing all Europeans to acquire the competences necessary to communicate in several languages and to have the possibility of experiencing different cultures. This is now:

3. See the Euromosaic study at: http://europa.eu.int/comm/education/policies/lang/languages/langmin/ euromosaic/index_en.html

4. Official Journal C 364, 18.12.2000: 1.

5. Barcelona European Council, 15 and 16 March 2002, Presidency Conclusions, part I, 43.1. 
- a right and a necessity;

- the basis for intensified co-operation, whether it be bilateral, trilateral or multilateral, local and trans-border, professional or economic, cultural or university-related, individual or within the framework of an association;

- the guarantee for increased mobility and exchanges;

- the assurance of better access to information through media and ICT.

The challenge is formidable for language teachers and schools (Vez, 2008: 2-3). First of all, they are faced with young people whose learning experiences succeed one another without ever coalescing to form a whole, and who play several roles and live in several time frames. Secondly, schools are faced with accelerating loss of community, which is weakening reference points both spatial and temporal (spatial, because the new communications media are bringing the distant close; temporal, because the collective memory based on the things that people have shaped and lived through together is being lost, scattered and fragmented into individual or group memories). This loss of community also leads to a break with the reality principle, as people surrender to the wish to follow their own urges and instincts. Thirdly, schools are faced with 'virtualisation', as the information networks detach themselves from human experience, with multimedia manufacturing an alternative reality, and the illustrated press increasingly relying on computer-generated images, rather than straight photographs. Lastly, schools are faced with the new emphasis on self-image, self-development and freedom of the individual, which disconnects people from group projects.

It is clear from this analysis that languages have a strategic role to play. It is also clearer why the $\mathrm{CE}$ and the EC have paid so much attention to language and culture. This is also why they are committed to projects and activities: i) which allow individuals and groups to overcome the language and culture barrier, and decompartmentalise education, training and research; ii) which promote and develop physical and virtual mobility; and iii) which help to give people a sense of belonging.

In which way are these projects and activities a guarantee for better schools and better language educators in a multilingual Europe? I shall now pay attention to the language and intercultural initiatives of the CE's Language Policy Division as valuable educational tools which have proved over the past few years to be a great contribution to an enrichment of what one may call "European togetherness", or European citizenship ('citoyenneté Européenne').

The research work of the Language Policy Division, widely known in the 1970s with the publication of The Threshold Level, was followed in the 1990s by the development of the Common European Framework of Reference for Languages: Learning, Teaching, Assessment (CEFRL) -published in 2001 (Council of Europe, 2001)- which: i) provides a common basis for the elaboration of language syllabuses, curriculum guidelines, examinations, textbooks, etc in a European dimension; ii) describes in a comprehensive way what language learners have to learn to do in order to use a language for communication and what knowledge and skills they have to develop so as to be able to act effectively; iii) defines a scale of 'common reference levels' of proficiency which allow learners' progress to be measured at each stage of learning and on a life-long basis; and iv) promotes an action-oriented approach to language learning in Europe. 
The European Language Portfolio (ELP) is another planning instrument which contributes to promoting learner autonomy and encourages life-long learning ${ }^{6}$. It reflects the CE's concern with respect for diversity of cultures and ways of life and is a tool to promote multilingualism and interculturalism through the integration of three elements: i) the language passport (describing intercultural learning experiences); ii) the language biography (including information on linguistic and cultural experiences gained in and outside formal educational contexts); and iii) the dossier (giving value to the heritage language or languages of oneself).

On the basis of examination of most of the interpretations and data presented so far, it may be argued that the $E L P^{7}$ can play an important role in this collaborative attempt to meet the challenge of multilingual and intercultural communication in our European school system: i) with its encouragement of all kinds of language learning; ii) with its objective of providing additional motivation for language learning in schools and encouraging mobility of European citizens; iii) with its role as a tool for social and professional integration; iv) with its potential comparison of language learning in different European countries; and v) with its importance as an interface and its need for diversification.

In October 2003, the Language Policy Division put forward its first pilot version of a Manual for relating Language Examinations to the CEFRL. This Manual ${ }^{8}$ is the result of a working group who has been able to put into practice the ideas and suggestions produced during the Helsinki Seminar in July 2002, in particular the need to assist member states, national and international providers of examinations, etc, in relating their certificates and diplomas to the CEFRL. The Manual will help users to: i) describe the examination coverage, administration and analysis procedures; ii) relate results reported from the examination to the common reference levels of the CEFRL; and iii) provide supporting evidence that reports the procedures followed to do so.

Much more recently, the Division has just launched the Autobiography of Intercultural Encounters ${ }^{9}$ which is currently being piloted throughout EU countries. As a tool to foster respect for diversity, dialogue and social inclusion, the Autobiography has been developed to promote intercultural dialogue guiding learners to think critically about an intercultural experience, i.e. an encounter with people from another social group (people from another country, from another ethnic group, from another religion, from another region of the same country, from another level or class or stratum of the same society). The Autobiography is accompanied by a Facilitator's Guide with details of the rationale, including the underlying model of intercultural competence, and specific guidelines concerning how to use and make the most of this tool.

But, in which way is all this support influencing the language professionals? Now that the CEFRL, the ELP, the Manual and the Autobiography have been launched and are being developed as powerful educational tools through intensive and extensive international cooperation, the language teaching profession has demanded more and more coherence and transparency in language certification from formal and informal EU institutions. The DIALANG

6. See: http://www.coe.int/t/dg4/portfolio/Default.asp?L=E\&M=/main_pages/welcome.html

7. It is worth noting that there is an American version of the ELP, called Linguafolio, which is now being trialled by 5 States. The Virginia Department of Education began a pilot phase of the LinguaFolio Virginia for high school and university students in 2004-2005. Since then the program has expanded to include five states: Virginia, North Carolina, South Carolina, Kentucky, and Georgia. See: http://www.doe.virginia.gov/linguafolio/index.html

8. See: http://www.coe.int/T/DG4/Linguistic/Manuel1_EN.asp\#TopOfPage

9. See: http://www.coe.int/t/dg4/linguistic\%5CAutobiogrWeb_EN.asp 
project and ALTE (Association of Language Testers in Europe) have already adopted the sixlevel scale of the CEFRL. But the mutual recognition of language qualification awarded by 'all' relevant EU institutions (in the sense that there is no doubt that a student's B1 in oral interaction obtained in a primary school in Granada is the same as the one given to a student in Leeds) is still a claim for the coming years. In that sense, the Manual aims to: i) contribute to competence building in the area of linking assessments to the CEFR; ii) encourage increased transparency on the part of examination providers; and iii) encourage the development of both formal and informal national and international networks of institutions and experts.

\section{Content and Language Integrated Learning (CLIL): An Effective Educational Provision?}

One of the first pieces of educational provision regarding European cooperation in CLIL is the 1995 Resolution of the Council ${ }^{10}$ which refers to the promotion of innovative methods and, in particular, to the teaching of classes in a foreign language for disciplines other than languages, providing bilingual teaching. Some years later, in 2003, the European Commission's Action Plan for the promotion of Language Learning and Linguistic Diversity 2004-2006 (COM (2003) 449 final) underlined the major contribution that the teaching of a subject through the medium of a foreign language (CLIL) can make to the Union's language learning goals. It is not so much what we know but how we use it which is so important when we consider effective language learning and communication. At the symposium held in Luxembourg on 10 and 11 March 2005, on 'The Changing European Classroom -the Potential of Plurilingual Education' stakeholders from the education world in the EU examined ways in which the study of subjects such as history, geography or biology and the acquisition of vocational skills through a foreign language could increasingly be incorporated in the member states' education and vocational training systems. The conclusions from this symposium were reported to the $2661^{\text {st }}$ Council meeting on 'Education, Youth and Culture' (9060/05 Presse 118: 19) in the following way:

1. There is a need for greater public awareness of the benefits of the CLIL approach and the contribution it could make to enhance individual and societal prosperity and social cohesion.

2. The promotion of CLIL could lead to increasing student and workforce mobility, thus reinforcing European citizenship.

3. Promotional bodies at national and EU level would be helpful to contribute towards the introduction, development, coordination and expansion of CLIL throughout the European Union.

4. Specific CLIL training for teachers and educational administrators should be encouraged, including a period of work or study in a country where the target language is generally spoken.

10. Council Resolution of 31 March 1995 on improving and diversifying language learning and teaching within the education systems of the European Union, Official Journal C 207 of 12.08.1995. 
5. Ways of acknowledging CLIL participation of learners at different educational levels are to be investigated.

6. A wide range of languages should be promoted as a medium for CLIL initiatives.

7. The exchange of information and scientific evidence on good CLIL practice should be encouraged at European level.

These conclusions are consistent with those provided by the Eurydice survey (Eurydice, 2006: 55) which is unquestionably an essential reference source on how CLIL is being developed in EU countries:

The CLIL methodological approach seeking to foster the integrated learning of languages and other areas of curricular content is a fast developing phenomenon in Europe. At the European level, interest is growing in the approach which, according to various experts, carries with it many benefits for pupils and students. EU initiatives in the field of CLIL have increased in recent years. Underlying them is the belief that young people should be more effectively prepared for the (multi)lingual and cultural requirements of a Europe in which mobility is expanding.

Aware of this challenge, national policy-makers in the field of education are taking a greater interest in CLIL and offering a wide variety of initiatives consistent with the different circumstances facing them. The present Eurydice survey has sought to review the diversity of this kind of provision in European countries. It is concerned solely with school contexts (other than language lessons) in which various subjects in the curriculum are taught using at least two languages.

Complementing the national profiles reported in the Eurydice survey, various teacherbased publications (Maljers, Marsh and Wolff, 2007; Marsh and Wolff, 2007; Mehisto, Marsh and Frigols, 2008) within the framework of the European Centre for Modern Languages in Graz (ECML) provide insights into how CLIL is being carried out in more than 20 European countries. One important concluding fact, transversal to all these studies, is the predominance of the English language. If the pre-eminence of Global English is absolutely clear in EU schools as far as conventional foreign language teaching is concerned (Eurydice, 2005), this is also the case when we deal with CLIL provision, although it has been an opportunity for incorporating a greater number of other EU languages like French, Spanish, German and Italian. Although this type of education resembles the classic immersion type of school, one important difference stands out: contrary to some immersion programmes, CLIL does give an important role to traditional language teaching. The relationship between these two facts, I suggest, is a possible interpretation to the provision of multilingual education programmes integrating Global English and linguistic diversity.

\section{Developing a Holistic Language Education Policy Inclusive of Global English and Linguistic Diversity}

Up to which point is it possible? Do we really believe it can work? Being optimistic about Europe, I do defend the potential of this kind of inclusive language education. In the same way as the proposals (mainly concerning the concept of a 'personal adoptive language') 
submitted by the so-called Group of Intellectuals ${ }^{11}$ set up to advise the Commission on the contribution of multilingualism to Intercultural Dialogue, I firmly believe that multilingualism can foster intercultural dialogue and mutual understanding, establishing a clear link between linguistic diversity and European integration. Participation in multilateral settings seems indeed to call for lingua franca communication in all public fori. It may well be that in concrete situations in public encounters the choice of other languages than English as lingua franca, and even the choice of several languages within the same discourse, turns out to be possible. This would, however, not invalidate the stance that in the forum of public mass media, only the use of lingua franca communication via Global English, on the basis of a rather small range of languages, would be able to ensure equal participation.

Of course we should admit that there is a danger of an 'English-only Europe', in the terms posed by Phillipson (2002), but this threat is just diminished to a mere anecdotal question when we have a look at real daily scenarios which increasingly reveal that the European communicative sphere produces a multitude of various settings with a wealth of different communicative needs. It indicates that every European is situated in a multilingual environment which structures her/his opportunities for communicative participation.

More and more European children grow up multilingual. They are unlike immigrants born in one culture and having to grow up in another, and they are unlike children growing up in a monolingual, monocultural family that happen to be located in a wider multicultural environment. For the children I am talking about, cultural and linguistic diversity is not just outside them in the society at large; it is part of themselves, and it is implanted in their minds as a novel kind of cultural identity. Multilingualism is going to become an existential condition in Europe, and this is really good news for a context in which national identities have been so powerful and have caused so much pain and tragedy in the past.

But, is multilingual education worth the effort? Is it worth the cost? Multilingualism however is not only an existential condition: it has also an impact on our cognitive life. Recent research in developmental psychology (Karmiloff and Karmiloff-Smith, 2001; Scholl and Leslie, 2001) shows that plurilingual children are faster in developing the ability to understand the mental states of others. Children with plurilingual competences, intriguingly, succeed in what is known as the «False Belief Task» (Emond and Ferres, 2001) several months earlier than do monolingual. A likely interpretation of these findings is that they have a more fine-grained ability to understand their social environment, and in particular, a greater awareness of the fact that different people may represent reality in different ways.

There is not yet solid empirical evidence from EU countries on which to base definitive claims about the educational (or other) advantages of multilingual education. But we do have plenty of negative evidence that monolingual models are ineffective. So any practice, system, or technology which offers hope and opportunity ought to be valued very highly, offsetting

11. The group, chaired by Amin Maalouf, was created in the context of the European Year of Intercultural Dialogue 2008 and delivered its report, entitled 'A rewarding challenge', to Commissioner Orban in February 2008. One main point can be identified from the proposal: The EU should promote the concept of a "personal adoptive language", to be seen as a "second mother tongue" with every European citizen being motivated to learn one. It would need to be part and parcel of everyone's school education/university studies and professional life, closely linked to aspects involving history, culture and literature. This adopted language would not normally be the one used for international communication. 
many, if not all, of the up-front costs of making such help available. There are less tangible costs to consider -political costs, social costs, cultural costs, etc. Even in these areas, there is room to argue the positive benefits of multilingual education. Thomas and Collier (1997) suggest that the best models of multilingual education also bring strong positive benefits in terms of vertical social integration and positive attitudes towards minority languages and cultures. The cost is high, but hard to measure. Vigorous debate will continue on both sides of the issue. But, the evidence is mounting that the 'real' answer is a strong "Yes!"

And, up to which point is this kind of 'inclusive' multilingualism a policy development based on language ideology? Of course it is. Decisions concerning a language policy are always based on some ideology. On the one hand, ordinary multilingualism reflects the linguistic relationship between its user-community and another community and, in most cases, contains a value judgment. According to Cobarrubias (1983), language policies are essentially based on ideologies that are assimilationist, pluralist, vernacular or tending to internationalism. The first two ideologies study the relationship between languages or language variations co-existing in one country in order to decide on the number of languages or language variations to recognise officially. The latter two determine the area from which the standard to be chosen and codified will be taken. This can be either the local language (or language variation) or a universal language (or another variation used as a standard elsewhere).

On the other hand, inclusive multilingualism reflects the educational development of a consciousness for the significance of plurilingual competences for participation in democratic and other social processes in EU countries. As Vollmer (2001) suggests, in inclusive multilingual policies we are obliged to teach the communicative tools with which speakers may accommodate and negotiate linguistic decisions, and the teaching of Global English may even become more likely for other languages to enter the European discourse. Indeed, Janssen (1999: 46) refers to 'a type of non-coordinated language drift' which is at work in favour of English and is characterised by the phenomenon that 'the competent use of the English language ensures the speaker's dominance in any type of communication between speakers from European countries'. In this respect I fully agree with Janssen when she concludes (1999: 50-51) that English language proficiency should be an indispensable aim of foreign language education since any form of 'broken or fragmented 'Euro-English' would give rise to language conflict. Thus, if the teaching of Global English under multilingual policies were to be restricted, as some authors suggest (Dabène, 1994; Quemada, 1995; Simon, 1995), to selected parts of communicative competence, or an English-based system of 'minimal communication', or a restriction of English to only receptive abilities, the expectable result would be a strengthening of a covert linguicism:

Furthermore, neither of these solutions sufficiently reflects the influence of social and cultural attitudes on learning a foreign (not simply, a second) language -in particular, the New Localism accompanied by the negative tendency of increasing linguistic and cultural distance. Neglecting these attitudes could provoke severe language conflicts and the establishment of new and more negative attitudes towards the English language and/or the implementation of English from outside or above, which in turn could then only be experienced as a kind of linguistic imperialism. It should once again be emphasized that it is not the English language that will cause conflicts but the conversational and attitudinal use of it, particularly when applied without negotiation within a discourse, and, above all, the decisive step to restrict the teaching to deficient competences. (Janssen, 1999: 51) 
The point Janssen makes is that the teaching of Global English with the aim of high proficiency can and should be welcomed as long as the individual and collective language rights of the multilingual EU learners are being protected at schools. The lack of multilingualism, which includes deficient competence in English, might do as much harm as the devaluation of linguistic diversity in terms of democratic citizenship. The same view is put forth by Huber (1998: 200), who pleads for a dispassionate acceptance of Global English as a lingua franca for the most basic communication in EU countries which leads to the freedom to learn and use other languages for educationally specific reasons such as intercultural exchange.

There can be no question that the freedom of choice of language is a fundamental cultural right. Furthermore, in multilingual settings, it seems just as urgent that people can participate in public communication without being subject to dominant language use. Therefore the right to use one's own language and communicative competence (of various degrees) in other languages must be seen as complementary elements for democratic EU citizenship. Negotiation of language choice and participation in public discourse on problems relevant to the polity require complex linguistic repertoires which individuals will have to develop and be able to rely on in their communicative practice. In this, education for EU democratic citizenship, linguistic diversity and inclusive multilingualism are not separate matters but rather one and the same issue.

\section{Concluding Remarks}

The conclusion arising from the points detailed above is that a multilingual education policy can have different forms. In countries where language education is codified, the qualifications which result from the learning and teaching of different languages have a legal framework and are certified by the ministry concerned, the regional authorities and school administrations. Where the codified language policy does not exist, the qualifications and the conditions for multilingual language education are generally arranged separately. It seems that European practice tends to reflect the latter version so that, as a result, languages appear as traditional disciplines in educational programmes or are used for learning subject matter (CLIL approaches) instead of being a subject itself. There are few examples of instances where the acquisition and learning of multicultural knowledge and linguistic abilities appear as a unifying factor in the educational process and thus create an appropriate plurilingual school environment.

Whose task is it to formulate the language policy of a country, a region or a conurbation? In a democracy, I believe that the elected bodies are in the best position to define the language policy. They can harmonise the various interests, they know and represent the nation and the national minorities of a country, they are able to understand and identify with the multicultural and language values. In my opinion it is the parliament whose task it is to formulate the language policy of a country as to codify the law, whereas at a local level, based on national policy and taking all possible specific regional features into account, it is the local authorities that should define the language policy of a region or a conurbation.

But, does a close connection exist between language policy and language education policy? A strong affirmative answer would mean that each country (region, conurbation) 
possesses a precise, codified language policy or at least a policy that is openly available to the public. However, this is not the case in several EU members. I believe that, in the real situation, it is the school that must introduce the form of language education into their programme, and change the school environment in order to offer students, as an almost natural step, a truly diverse and multicoloured cultural and linguistic resource. A resource which should be developed in such a way that students are not only being taught several languages, but their interest is also being aroused in the discovery of other identities and cultures and in becoming plurilingual European citizens.

If the political and educational aims are geared towards communicative integration in Europe, two factors -linguistic unity and linguistic diversity- have to be taken into account. European communicative integration is in itself a function of the process of European integration in a more general sense. The fact that English is the most widely-taught foreign language in EU countries does not imply that its teaching is always embedded in a holistic concept of language education for democratic citizenship. EU citizens' acceptance of policies for European integration probably depends to a large extent on their ability and willingness to participate in a European public debate. Here, proficiency in English as a possible and reliable interlingua mediator and the equality of people's linguistic identities will have to play equal parts in any multilingual education policy. As David Graddol (2006: 58) has recently put it: "Global English may represent an important discontinuity with the past, rather than the triumph of Modern English on the world stage". The point made here is that in policies for multilingual education, linguistic diversity and the teaching of English are not a matter of priorities. Any policy which treats multilingualism as an 'either - or' decision runs the risk of creating social exclusion either through cultural or political exclusion. To put the same thought in a positive way: sustainable cultural and political inclusion, which can lead to opportunities of participation in multilingual Europe, requires a holistic language education policy inclusive of English and linguistic diversity.

I believe that active inclusive multilingualism in Europe will help produce a new generation of cognitively more flexible school children who, from the outset, will have integrated their mixed cultural background in their own identity and their own cognition. It will become impossible for EU educational institutions to inflict on these individually multicultural students their local 'sacred values' based on higher civilization, greater bravery, spiritual superiority, or whatever. They will have to update their educational programs for young people who recognize themselves neither in local foundational myths, nor in a feel-good multiculturalism predicated upon the maintenance of sharply distinct cultural identities. This will help new generations to get rid of 'unreal loyalties', to use the words of Virginia Woolf, to nation, flag or local customs and manners. Multilingual citizens of a European space will be more tolerant and less sensitive to local allegiances and partialities. Their tolerance of diverse cultural identities, in the old 'mono' style or recomposed, will be built from within, and not learned as a social norm. All this may be just wishful thinking, but I can't help thinking that being multilingual is the best and cheapest antidote to cultural intolerance to be found today. And it is a way of going beyond the empty label of 'multiculturalism' by experiencing a plural culture and plurilingual competences from within. But, of course, this is not just a European issue. 


\section{REFERENCES}

Alcón, E. and Safont, M. P. (eds.) (2008). Intercultural Language Use and Language Learning. Berlin: Springer.

Baetens Beardsmore, H. (ed.) (1993). European models of bilingual education. Clevedon: Multilingual Matters.

Baetens Beardsmore, H. and Swain, M. (1985). Designing bilingual education: Aspects of Immersion and European School Models. Journal of Multilingual and Multicultural Development, 6 (1): 1-15.

Baker, C. (1996). Foundations of Bilingual Education and Bilingualism. Clevedon: Multilingual Matters.

Bhatia, T. K. and Ritchie, W. (eds.) (2004). Handbook of Bilingualism and Multiculturalism. Malden: Blackwell.

Candelier, M. (ed.) (2003). Evlang -L'éveil aux langues à l'école primaire. Brussels: De BoeckDuculot.

Cenoz, J. and Jessner, U. (eds.) (2000). English in Europe. The acquisition of a third language. Clevedon: Multilingual Matters.

Christian, D. and Genesee, F. (eds.) (2001). Bilingual Education. Alexandria: TESOL.

Cobarrubias, J. (1983). "Ethical issues in status planning". In Cobarrubias, J. and J. A. Fishman (eds.). Progress in language planning. International perspectives, 41-85. Berlin: Mouton.

Council of Europe (2000). The Modern Languages Project. Retrieved in April 12, 2005, from http://culture.coc.fr/lang.eng/Doc_info_text_E_brochure.html

Council of Europe (2001). The Common European Framework of Reference for Languages: Learning, Teaching, Assessment. Cambridge: Cambridge University Press.

Council of Europe (2007). From Linguistic Diversity to Plurilingual Education: Guide for the Development of Language Education Policies in Europe. Main version. Strasbourg: Council of Europe. (Also available at: http://www.coe.int/lang).

Dabène, L. (1994). Repères sociolinguistiques pour l'enseignement des langues. Paris: Hachette.

De Bot, K., Lowie, W. and Verspoor, M. (2007). A Dynamic Systems Theory approach to second language acquisition. Bilingualism: Language and Cognition, 10 (1): 7-21.

Emond, B. and Ferres, L. (2001). Modeling the False-Belief Task: An ACT-R Implementation of Wimmer and Perner -1983. Besançon: Conference for Conceptual and Linguistic Development.

European Commission (2005). Communication from the Commission to the Council, the European Parliament, the European Economic and Social Committee and the Committee of the Regions: A New Framework Strategy for Multilingualism (COM 2005, 596 final). Retrieved in April 3, 2008, from http://europa.eu/languages/en/document/74

European Economic Community (1990). Secondary Schools and European/International Education in Europe: Mobility, Curricula, and Examinations. Brussels: Namur.

Eurydice (2005). Key data on teaching languages at school in Europe. Brussels: Eurydice European Unit. (Also available at: http://www.eurydice.org/

Eurydice (2006). Content and Language Integrated Learning (CLIL) at School in Europe. Brussels: Eurydice European Unit. (Also available at: http://www.eurydice.org/

Graddol. D. (2006). English Next. Why Global English may mean the end of 'English as a Foreign Language'. London: British Council. 
Hamers, J. and Blanc, M. (1989). Bilinguality and bilingualism. Cambridge: Cambridge University Press.

Hoffmann, C. (1998). "Luxemburg and the European schools". In J. Cenoz and F. Genesee (eds.). Beyond bilingualism: Multilingualism and multilingual education, 143-174. Clevedon: Multilingual Matters.

Housen, A. (1997). "Teaching and learning second languages in the European Schools". In K. Karavas-Doukas and P. Rea-Dickins (eds.). The teaching of foreign languages in primary schools in Europe, 40-53. Coventry: University of Warwick Press.

Housen, A. (2002). "Second language achievement in the European School system of multilingual education”. In D. So and G. Jones (eds.). Education and Society in Plurilingual Contexts, 96-127. Brussels: VUBPress.

Housen, A. and Pallotti, G. (2002). "Interlanguage development at primary school: The acquisition of English by young Italian-speaking learners in different socio-educational contexts". In P. Rea-Dickins (ed.). The teaching and learning of foreign languages in European primary schools, 83-102. Cambridge: Cambridge University Press.

Huber, L. (1998). Lingua Franca und Gemeinsprache. Gehört zur Allgemeinen Bildung eine gemeinsame Sprache? In I. Gogolin, M. Krüger-Potratz and M. Meyer (eds.). Pluralität und Bildung, 193-211. Opladen: Leske und Budrich.

Janssen, H. (1999). "Linguistic dominance or acculturation -problems of teaching English as a global language". In C. Gnutzmann (ed.). Teaching and Learning English as a Global Language, Native and Non-Native Perspectives, 41-55. Tübingen: Stauffenburg Verlag.

Karmiloff, K. and Karmiloff-Smith, A. (2001). Pathways to Language. Harvard: Harvard University Press.

Maljers, A., Marsh, D. and Wolff, D. (eds.) (2007). Windows on CLIL: Content and Language Integrated Learning in the European Spotlight. The Hague, European Platform for Dutch Education/Graz, European Centre for Modern Languages.

Marsh, D. and Wolff, D. (eds.) (2007). Diverse Contexts -Converging Goals: CLIL in Europe. Frankfurt: Peter Lang.

Mehisto, P., Marsh, D. and Frigols, M. (2008). Uncovering CLIL: Content and Language Integrated Learning in Bilingual and Multilingual Education. Oxford: Macmillan.

Muller, A. and Beardsmore, H. B. (2004). Multilingual Interaction in Plurilingual Classes European School Practice. Bilingual Education and Bilingualism, 7 (1): 24-42.

Phillipson, R. (2002). English-only Europe? Language Policy Challenges. London: Routledge.

Quemada, B. (1995). "Apprendre à comprendre les langues". In J.-P. Atal et al. (ed.). Comprendre les langues, aujourd'hui, 9-14. Paris: La Tilv.

Scholl, B. and Leslie, A. (2001). Minds, Modules, and Meta-Analysis. Child Development, 72 (3): 696-701.

Sears, C. (1998). Second language pupils in mainstream classrooms: A handbook for teachers in international schools. Clevedon: Multilingual Matters.

Sheils, J. (1999). The European Language Portfolio: towards a democratic citizenship. Babylonia, 1: 6-7.

Simon, Diana-Lee. (1995). La mise en place de l'Europe à travers l'apprentissage des langues à l'école. Lidil, 11: 103-123.

Skutnabb-Kangas, T. (ed.) (1995). Multilingualism for All. Lisse: Swets and Zeitlinger.

Thomas, W. P. and Collier, V. (1997). School effectiveness for language minority students. Washington D. C.: National Clearinghouse for Bilingual Education. 
Trim, J. M. L. (1999). Common tools to promote linguistic and cultural diversity, respect, tolerance and understanding in Europe. Babylonia, 1: 8-9.

Vez, J. M. (2008). European Policies in TEFL Teacher Education. The Open Applied Linguistics Journal, 1: 1-8.

Vollmer, H. (2001). "Englisch und Mehrsprachigkeit: Interkulturelles Lernen durch Englisch als lingua franca?“. In D. Abendroth-Timmer and G. Bach (eds.). Mehrsprachiges Europa, 91-109. Tübingen: Narr. 